\title{
ARTIKKELIT
}

\section{Hyvä asuminen muistisairaana}

\author{
Erja Rappe ${ }^{1}$, Jere Rajaniemi ${ }^{1}$, Päivi Topo ${ }^{1}$
}

${ }^{1}$ Ikäinstituutti

\begin{abstract}
Muistisairaudet muuttavat suhdetta asuinympäristöön ja lisäävät asumiseen liittyvien palveluiden tarvetta. Tarkastelemme esimerkkikohteiden ja asiantuntijahaastattelujen pohjalta muistisairaiden ikäihmisten asumiseen liittyviä tekijöitä ja niiden yhteyttä toisiinsa sekä asukkaiden toimintamahdollisuuksiin. Muistiongelmien koetun vakavuuden yhteyttä toimintamahdollisuuksiin ja tyytyväisyyteen asuinympäristön laatutekijöihin selvitimme Sipoon kunnan asumispalveluiden asiakkaille tehdyn kyselytutkimuksen perusteella. Pääosin laadullisen aineiston jäsennyksen teoreettisena viitekehyksenä käytimme toimijaverkkoteoriaa ja tarjoumateoriaa. Keskeisiksi nousivat tekijät, jotka olivat yhteydessä asukkaiden mahdollisuuksiin vuorovaikutukseen, mielekkääseen tekemiseen ja liikkumiseen sekä omannäköiseen elämään. Siihen, miten asukkaat pystyivät näitä mahdollisuuksia käyttämään, vaikuttivat asumiseen liittyvien toimijoiden osittain ristiriitaisetkin pyrkimykset. Tuloksia voidaan hyödyntää asumisen kehittämisessä vastaamaan paremmin ikääntyvän väestön tarpeita.
\end{abstract}

\section{Johdanto}

Muistisairaudet vaikeuttavat jo varhaisessa vaiheessa sairastuneen kykyä hallita asuinympäristöään. Edetessään muistisairaus johtaa usein palveluasumiseen, vaikka kotona asumista pyritään eri keinoin tukemaan. Ennusteiden mukaan muistisairaiden ihmisten määrä tulee moninkertaistumaan lähitulevaisuudessa, mikä lisää tarvetta kehittää heille sopivia asumisenratkaisuja.

Muistisairaiden ihmisten asumista on tutkittu pääosin erilaisissa palveluasumisen ratkaisuissa hoitoympäristön näkökulmasta (esim. Charassa, Eynardb \& Viatoura 2016; Hadjri, Rooney \& Faith 2015) tai on vertailtu erilais- ten ratkaisujen vaikutuksia asukkaiden elämänlaatuun (esim. de Rooij ym. 2012). Kokonaisvaltainen näkemys siitä, mitkä tekijät vaikuttavat muistisairaiden ihmisten asumisen suunnitteluun ja käytäntöihin ja miten eri tekijät ovat yhteydessä toisiinsa ja muistisairaiden asukkaiden hyvinvointiin, kuitenkin puuttuu.

Ymmärtääksemme asumista fyysisen ja psykososiaalisen ympäristön sekä ympäröivän yhteisön ja yhteiskunnan sosiaalisten, kulttuuristen ja toiminnallisten rakenteiden muodostamassa kokonaisuudessa paremmin muistisairaiden ihmisten näkökulmasta, tarkastelemme asumista moniulotteisesti ja pohdimme, miten siihen liittyvät tekijät kytkeytyvät toisiinsa. Nostamme esiin kaksi teoreettista lähestymis- 
tapaa, joissa korostuvat erilaisista toimijoista muodostuvat dynaamiset verkostot sekä yksilön toiminnan mahdollisuudet ympäristössä.

\section{Toimijat ja tarjoumat}

Aineiston jäsentelyssä käytämme toimijaverkkoteoriaa (Callon 1986) ja tarjoumateoriaa (Gibson 1979; Heft 2010), jotka tuovat esille toiminnan prosessit ja asioiden ilmenemisen relationaalisesti, suhteiden kautta tekijöiden kohdatessa toisensa. Toimijaverkkoteoria avaa näkökulman ympäristön rakentumiseen ja muokkautumiseen laajempana fyysisenä ja sosiaalisena ilmiönä, tarjoumateoria puolestaan valaisee ympäristön merkitystä yksilöiden toiminnalle ja kokemuksellisuudelle.

Asumista tukevat verkostot mielletään yleensä ihmisistä ja instituutioista koostuviksi. Keskeisinä toimijoina nähdään etenkin kunta eri hallinnonaloineen sekä järjestöt, yritykset, ikäihmiset itse ja heidän läheisensä. Tätä näkökulmaa on kuitenkin hyvä laajentaa toimijaverkkoteorialla, jossa myös fyysinen ympäristö, esineet, tieto sekä ajattelu- ja toimintamallit omalla olemassaolollaan mahdollistavat tai rajoittavat toimintaa (Jolanki ym. 2017). Muistisairauksien yhteydessä toimijaverkkoteorian avulla on tarkasteltu materiaalisten tekijöiden vaikutusta hoidon käytänteiden muotoutumiseen hoitoyksiköissä (Araujo, Velloso, Câncio, Ceci \& Purkis 2019; Driessen 2019, Nord 2015). Kun tarkastelua laajennetaan hoitoyksikön ulkopuolelle ulottuvaan fyysiseen ja organisaatiolliseen ympäristöön, asuinympäristön yhteisölliset ja yhteiskunnalliset ulottuvuudet tulevat näkyviksi.

Toimijaverkkoteorian lähtökohdat ovat tieteen ja teknologian tutkimuksessa. Suuntauksen keskeisiä vaikuttajia ovat olleet muun muassa Michel Callon (1986) ja Bruno Latour (2005). Toimijaverkko tai toimijaverkosto on Kullmanin ja Pyyhtisen (2015) mukaan varsinaisen teorian sijaan ennemmin lähestymistapa, joka suuntaa huomion ihmisten, teknologian ja luonnon väliseen jatkuvaan vuorovaikutukseen ja siihen, miten asiat rakentuvat moninaisissa ja alati muuttuvissa suhteissa. Tarkastelun kohteeksi määrittyy näin avoin ja liikkeessä oleva suhteiden verkko, jossa niin inhimilliset kuin ei-inhimillisetkin toimijat määrittelevät ja ohjailevat toistensa toimintaa.

Toimijaverkoston näkökulmasta esimerkiksi asumispoliittiset tavoitteet eivät kehity vain ylätason poliittisissa ohjelmissa, vaan myös arjen asumisratkaisuissa, jotka eri tavoin konkretisoivat, vahvistavat tai haastavat vallitsevaa asumispolitiikkaa. Toimijaverkkoteoriassa lähtöolettamus on jatkuvan muutoksen olemassaolo ja kiinnostuksen kohde on nimenomaan verkostojen epävakaudessa ja niissä olevien jännitteiden ymmärtämisessä (Kullman \& Pyyhtinen 2015).

Koska toimijaverkkoteoria ohjaa tulkitsemaan toimijoiksi myös muita kuin inhimillisiä ja konkreettisia toimijoita, se tuo näkyviin niin rakennusten ja teknologian kuin vallitsevien toimintamallien ja hoitofilosofioidenkin merkityksen toiminnan suuntaamisessa. Toimijaverkkoteorian näkökulmasta voidaan tarkastella myös sitä, kuinka ihmisten luomat ympäristöt - rakennettu ympäristö ja esineympäristö - ilmentävät ja tuottavat vallitsevia hoitofilosofioita ja toimintamalleja (Nord 2015).

Tarjoumateoriaa on hyödynnetty muistiystävällisessä suunnittelussa (Chen \& Liu 2017) ja muistisairaiden hoitoyksikköjen kehittämistarpeiden arvioinnissa (Topo, Kotilainen \& Eloniemi-Sulkava 2012). Tarjoumateorian kautta asumisen ympäristöjä voidaan tarkastella havaitun ympäristön tulkittuina toimintamahdollisuuksina. Teorian mukaan toiminnan mahdollisuus eli tarjouma syntyy yksilön ja ympäristön vuorovaikutuksessa (Kyttä \& Kahila 2006) ja se kuvaa niitä ympäristön piirteitä, jotka ovat yksilölle toiminnallisesti merkityksellisiä (Heft 2010). Ympäristössä olevat yksilölliset mahdollisuudet toiminnalle avautuvat havainnoinnin kautta (Chemero 2003; Gibson 1979; Heft 2010). Tarjouman havaitseminen perustuu vallitsevan ympäristön vä- 
littömään tulkintaan toiminnan mahdollistajana tai rajoittajana (Canal-Bruland \& van der Kamp 2015; Heft 2010). Vaikka tarjoumat havaitaan yksilöllisesti, niistä monet ovat sosiaalisesti jaettuja, yhteisiä (Heft 2010). Tarjouman käsite voidaan laajentaa käsittämään toiminnan lisäksi ympäristön yksilölle tarjoamat emotionaaliset, sosiaaliset sekä sosiokulttuuriset mahdollisuudet ja rajoitukset (Kyttä 2003). Tarjouman hyödyntäminen toteutuneeksi toiminnaksi, aktualisointi, puolestaan edellyttää, että yksilön kyvyt, tarpeet ja aikomukset muodostavat ympäristön kanssa merkityksellisen kokonaisuuden (Kyttä 2004). Siihen, mitkä tarjoumat aktualisoidaan ja missä tilanteissa, vaikuttavat yksilöllisten ominaisuuksien lisäksi sosiokulttuuriset tekijät (Kyttä 2002).

Tarjoumat voidaan käsittää myös laatutekijöiksi ja tarkastella niiden tilallista ja ajallista sijoittumista sekä saavutettavuutta asuinympäristössä (Kyttä \& Kahila 2006). Tällöin tarjoumien kautta on mahdollista ilmentää sitä, kuinka ympäristön ominaisuudet ovat yhteydessä asukkaiden kokemuksiin, tarpeiden tyydyttymiseen ja käyttäytymiseen.

Muistisairaiden ihmisten hyvinvoinnin ja elämänlaadun arviointia pidetään haasteellisena ja siihen vaikuttavat monet tekijät (Banerjee ym. 2006). Elämän kokeminen merkitykselliseksi (Dewitte, Vandenbulcke \& Dezutter 2019) ja oman persoonallisuuden säilyttäminen ovat muistisairaan hyvinvoinnille keskeisiä (Kitwood \& Bredin 1992). Etenevät muistisairaudet vaikeuttavat ympäristön hallintaa monin tavoin aisteissa ja aistitiedon tulkinnassa tapahtuvien muutosten vuoksi. Asuinympäristön tuttuus, helppo hahmotettavuus, toimintaa tukeva aistitieto ja esteettömyys helpottavat muistisairaiden ihmisten arkea toimintakyvyn heiketessä (Rappe, Kotilainen, Rajaniemi \& Topo 2018).

Muistisairauksiin liittyy usein haasteellista käyttäytymistä ja mielialaongelmia, joita mielekkääksi koettu toiminta voi lievittää (Testad ym. 2014). Merkityksellinen tekeminen voi vahvistaa persoonallisuutta (Milte ym.2016) ja fyysisen aktiivisuus ylläpitää ja edistää kognitiota, mielialaa ja päivittäisten toimien sujumista sekä vähentää levottomuutta (Brett, Traynor \& Stapley 2016). Yhteenkuulumisen ja yhteisöllisyyden kokemukset edistävät muistisairaiden hyvinvointia (Brooker, Argyle, Scully \& Clancy 2011). Kommunikaatiokykyjen heiketessä ympäristön myönteinen, hyväksyvä ja kannustava asenneilmapiiri tulee yhä tärkeämmäksi, mikä korostaa vuorovaikutuksen merkitystä muistisairautta sairastavien hyvinvoinnille.

Muistisairauksilla on laaja-alaisia vaikutuksia sairastuneen muistitoimintoihin, päivittäiseen toimintaan ja sosiaaliseen elämään.Tämän vuoksi asuinympäristön tarkastelu fyysisenä, rakenteellisena ja kokemuksellisena ilmiönä voi lisätä ymmärrystä muistisairautta sairastavien asumisesta ja asumiseen liittyvistä tarpeista. Toimijaverkkoteoria valaisee ympäristön fyysistä ja toiminnallista rakentumista, tarjoumateoria puolestaan toiminnan mahdollisuuksien havaitsemista ja tulkintaa asukkaan näkökulmasta. Kun asuinympäristöä tarkastellaan samanaikaisesti toimijoiden muodostaman verkoston sekä siinä havaittujen yksilöllisten toimintamahdollisuuksien kanssa, tulee näkyväksi se, miten eri toimijat ovat yhteydessä joko suoraan tai välillisesti yksilöiden kokemukselliseen ympäristöön.

Tässä artikkelissa tavoitteemme on tunnistaa muistisairautta sairastavien ihmisten asumiseen liittyviä toimijoita ja tarjoumia sekä analysoida näiden tekijöiden keskinäisiä suhteita ja yhteyksiä hyvinvointiin. Pyrkimyksenämme on ymmärtää sitä osin jännitteistä todellisuutta, missä asumisen suunnittelu ja järjestäminen toteutuvat. Tuloksia voidaan hyödyntää asumisen kehittämisessä vastaamaan paremmin ikääntyvän väestön tarpeita.

\section{Aineisto ja menetelmät}

Artikkeli perustuu kirjoittajien Asumisen uudet vaibtoebdot ja hyvä vanhuus (Asuva) -hankkeessa vuosina 2016-2017 keräämään aineistoon 
muistisairaiden ikäihmisten asumisesta. Asuvahankkeessa selvitettiin ikääntyneiden yhteisöllistä asumista ja asumisen yhteisöllisyyttä asuinalueilla (Jolanki ym. 2017). Valtioneuvoston kanslian rahoittaman (VN TEAS) hankkeen toteutuksesta vastasivat Tampereen yliopisto, tutkimus- ja kehittämiskeskus GeroCenter, Ikäinstituutti ja Jyväskylän yliopisto.

Artikkelin aineisto koostuu kohde-esimerkeistä, muistisairautta sairastavien ihmisten asumiseen liittyvien asiantuntijoiden haastatteluista ja niissä esiin nousseista vanhusten asumista ja palveluita ohjaavasta lainsäädännöstä ja suosituksista sekä kyselyaineistosta. Aineisto kuvastaa asumista kotona asumisesta laitosasumiseen keskittyen asumispalveluihin.

Muistisairautta sairastavien ikäihmisten asumiseen ja sen järjestämiseen tutustuttiin Suomessa neljässä kohteessa (Juuan Hoito ja Hoiva, Villa Tapiola, Sipoon kunta ja Helsingin kaupunki) ja ulkomailla viidessä kohteessa (Alterszentrum Gibeleich ja Reusspark Sveitsissä, Camillo Golgi Instituutti Italiassa sekä Maison de Retraite Valrosé ja Logement Foyer Saint Jean d'Angely Ranskassa). Aineisto muodostui palveluiden tuottajien edustajien yksilö- ja ryhmähaastatteluista (11 kpl), havaintomuistiinpanoista ja valokuvista sekä kotimaisista asiantuntijahaastatteluista $(6 \mathrm{kpl})$. Asiantuntijat edustivat Asumisen rahoitus- ja kehittämiskeskusta, Aalto yliopiston arkkitehtuurin laitosta, yksityistä kotipalvelujen tuottajaa ja kunnallisia johtavia toimihenkilöitä. Asiantuntijana oli myös muistisairas henkilö, joka asui omassa kodissaan ja toimi Muistiliiton muistiaktiivina. Haastattelut tallennettiin digitaalisesti ja litteroitiin asumiseen liittyvien teemojen osalta.

Analyysissä tarkastelimme aineistoa esimerkkikohteiden ja haastattelujen kokonaisuutena. Aineistoon kuuluva kyselyaineisto analysoitiin omana kokonaisuutenaan ja sen tulokset esitetään erikseen. Tekstuaalinen aineisto analysoitiin hyödyntäen laadullista sisällönanalyysiä aineistolähtöisesti (Tuomi \& Sarajärvi 2013) ja huomio kiinnitettiin muistisairaiden asukkaiden asumisen muotoutumiseen ja hyvinvointiin liittyviin tekijöihin. Moniulotteisen aineiston luokittelussa ja jäsentämisessä ymmärrettäväksi kokonaisuudeksi hyödynsimme toimijan ja tarjouman teoreettisia käsitteitä ja pohdimme niiden välisiä suhteita.

Sipoon kunnan asumispalveluiden asiakkaille tehtiin lomakekysely, jonka avulla tarkasteltiin muistiongelmien koetun vakavuuden yhteyttä toimintamahdollisuuksiin asuinympäristössä sekä tyytyväisyyttä asuinympäristön laatuun. Kyselylle saatiin lupa Sipoon kunnan vanhuspalveluista ja sen toteuttivat kunnan ikääntyneiden palveluiden henkilökunta. Henkilökunta informoi osallistujia ja omaisia tutkimuksesta, kysyi suostumuksen osallistujilta henkilökohtaisesti ja auttoi tarvittaessa vastaamisessa. Kysely tehtiin sekä suomen- että ruotsinkielisenä ja siihen vastattiin nimettömänä. Osallistuminen oli vapaaehtoista ja sen sai keskeyttää niin halutessaan.

Kysely pohjautui Sense of Community Indexiin, jonka perustana olevan teorian mukaan yhteisöllisyyden kokemukseen liittyy osallisena olemisen, vaikuttamisen, tarpeiden tyydyttymisen ja jaettujen tunteiden ulottuvuudet (McMillan \& Chavis 1986). Nämä ulottuvuudet ovat yhteydessä muistisairaiden koettuun hyvinvointiin. Kyselyssä oli 30 kysymystä, joihin sisältyi pääosin valmiit vastausvaihtoehdot. Niiden soveltuvuutta kohderyhmälle varmistettiin testaamalla kysely etukäteen ja tekemällä palautteen perusteella muutoksia kysymysten muotoiluun ja lomakkeen ulkoasuun.

Kyselyyn saatiin yhteensä 37 vastausta. Vastaajista 10 asui omassa kodissaan ja 27 asumisyksiköissä. Vastaajien keski-ikä oli 82,4 vuotta. Nuorin vastaaja oli 63-vuotias ja vanhin 95-vuotias. Naisia vastaajista oli 78 prosenttia. Vastaajista 35 prosenttia ilmoitti kokevansa paljon ja 49 prosenttia jonkin verran muistamisvaikeuksia. Kyselyaineisto analysoitiin käyttäen riippumattomien otosten t-testiä ja Spearmanin järjestyskorrelaatiokerrointa $I B M$ SPSS Statistics 24 -ohjelmalla. 
Tarkastelemme tuloksissa asuinympäristön tarjoumia aineistosta nousseen toimijaverkon rakenteessa ja pohdimme tuloksia sekä tarjoumien aktualisoinnin ja muistisairaiden asukkaiden hyvinvoinnin kannalta.

\section{Tulokset - asumisen toimijat tarjoumien muovaajina}

Muistisairautta sairastavien ikäihmisten asumisessa keskeisiä toimijoita olivat asukkaat ja heidän omaisensa, asumispalveluiden henkilökunta ja johto sekä vapaaehtoiset ja järjestötoimijat. Esille tulivat myös lähiympäristön palvelujen merkitys sekä ikääntyneiden palvelujärjestelmän ja asumisen suunnittelujärjestelmän ohjaava vaikutus asumisen muotoutumiseen. Toimijaverkkoteorian näkökulmasta asumisen verkostoon kuuluivat myös rakennukset sisä- ja ulkotiloineen ja esineistöineen, teknologia, toimintakulttuurit, luonto ja viherympäristö sekä erilaiset kehittämisohjelmat tavoitteineen ja käsitteineen.

Luokittelimme esille tulleet toimijat asumisen yhteisöön, rakennukseen sisätiloineen, pihaan lähiympäristöineen, paikallisyhteisöön palveluineen sekä yhteiskuntaan sääntöineen ja järjestelmineen (Kuvio 1). Vaikka tuomme asumisen toimijat hahmottamisen helpottamiseksi esille hierarkkisena rakenteena, ohjaa toimijaverkkoteoria ymmärtämään, että asumiseen liittyvät asiat ovat elävässä elämässä toisiinsa kietoutuneena ja eri tilanteissa eri tavoin läsnä.

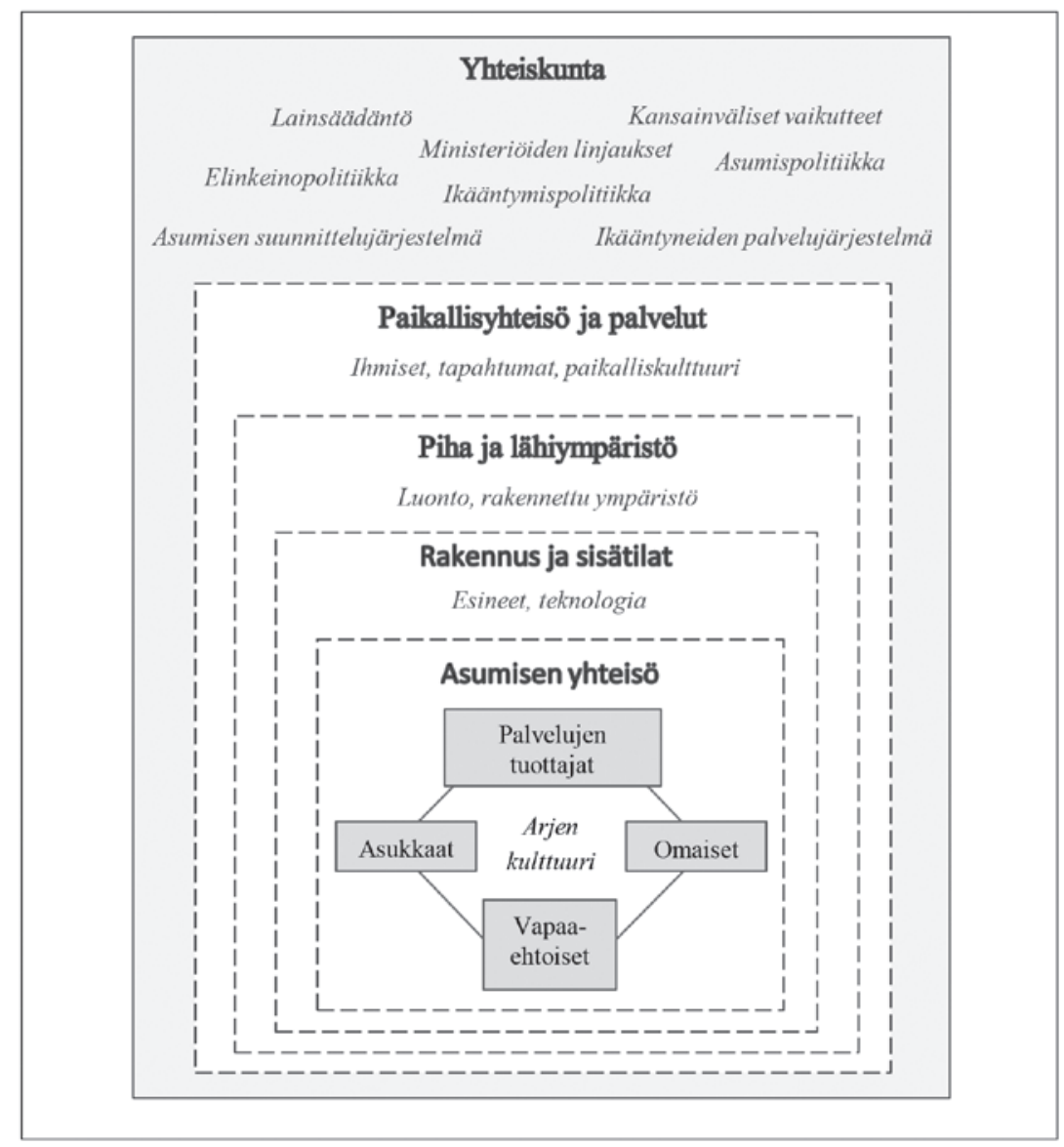

Kuvio 1. Asumisen toimijaverkon ulottuvundet 


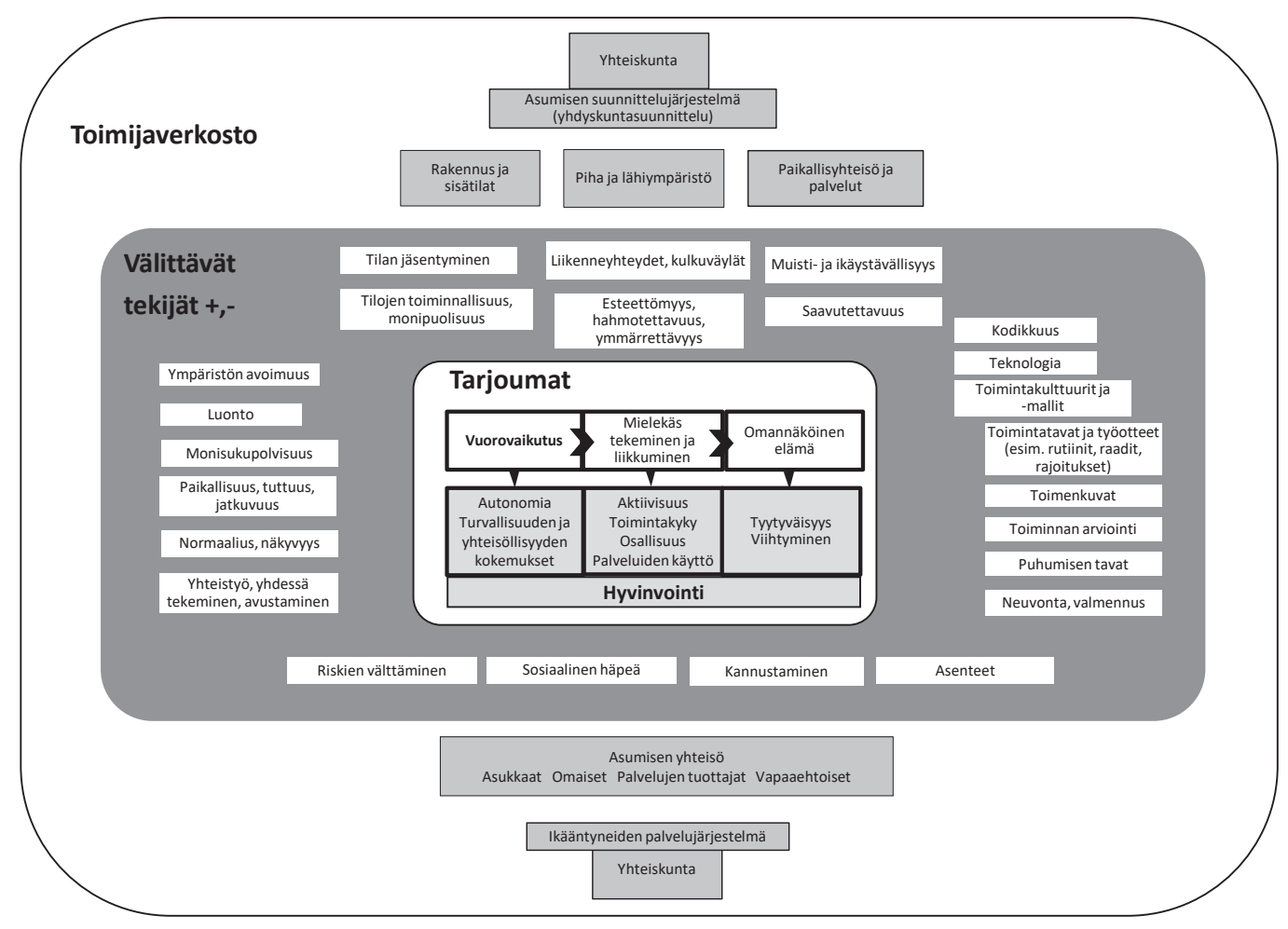

Kuvio 2. Muistisairaiden asukkaiden asumiseen liittyvä toimijaverkosto ja hyvinvoinnille keskeiset tarjoumat. Välittärät tekijät joko edistävät tai estävät tarjoumien aktualisointia.

Asuinympäristön tarjoumista muistisairautta sairastaville asukkaille keskeisiksi nousivat mahdollisuudet vuorovaikutukseen, mielekkääseen tekemiseen ja liikkumiseen sekä oman näköiseen elämään (Kuvio 2). Asukkaiden autonomialle, turvallisuuden ja yhteisöllisyyden kokemukselle vuorovaikutus oli tärkeää. Aktiivisuus, toimintakyvyn ylläpito, osallisuus ja palveluiden käyttö onnistuivat, mikäli tekemisen ja liikkumisen edellytykset toteutuivat. Mahdollisuudet elää omannäköistä elämää ilmenivät asukkaiden tyytyväisyytenä ja viihtymisenä.

Jaoimme toimijaverkon ulottuvuuksia $(\mathrm{Ku}-$ vio 1) kuvaaviin toimijoihin ja välittäviin tekijöihin, jotka joko edistivät tai ehkäisivät asukkaita aktualisoimaan tarjoumia (Kuvio 2). Seuraavassa kuvaamme yksityiskohtaisemmin toimijoiden yhteyttä tarjoumiin ja niiden aktualisointiin.

\section{Asumisen yhteisö}

Asumisen yhteisöjä oli joko omissa kodeissa tai palvelu- ja laitosasumisen yksiköissä. Toimintakulttuurit ja -mallit sekä teknologian käyttö välittivät asumisen yhteisössä sitä, millaiset mahdollisuudet asukkailla oli vuorovaikutukseen, mielekkääseen tekemiseen ja liikkumiseen sekä omannäköiseen elämään.

Asumispalveluissa toimintakulttuuri tuli näkyväksi pääosin henkilöiden välisen vuorovaikutuksen sisällön ja laadun kautta. Asenteet, käytössä olevat toimintamallit ja työotteet mahdollistivat, suuntasivat tai estivät asukkaiden ja heidän läheistensä vuorovaikutusta ja toimintaa. Palveluasumisessa henkilökunnan johdonmukainen ja asukkaiden yksilölliset piirteet huomioiva käytös, asukkaiden keskinäisen vuorovaikutuksen tukeminen sekä per- 
hesuhteiden jatkuvuus nähtiin asiantuntijoiden mukaan hyvinvointia edistävinä tekijöinä.

Kun hoiva ja hoito toteutettiin asukkaiden tarpeita ja toiveita kuunnellen eikä ennalta aikataulutettujen rutiinien puitteissa, tuettiin asukkaan autonomiaa. Asukkaiden osallistumismahdollisuuksia heitä koskevien asioiden suunnitteluun ja päätöksentekoon voitiin vahvistaa erilaisten asukaskokousten, raatien ja järjestötoiminnan avulla.

Yhteiset rutiinit, kuten ruokailu, loivat mahdollisuuksia asukkaiden keskinäiseen vuorovaikutukseen. Jos organisaation toimintakulttuuri mahdollisti läheisten osallistumisen konkreettisesti asukkaiden arkeen, se tuki perhesuhteiden jatkuvuutta. Läheisten toimintaan kohdistuvat rajoitteet, kuten vierailuajat tai yöpymismahdollisuuksien puute, korostivat asumisen institutionaalisuutta, kun taas mahdollisuudet tehdä arkisia toimia, kuten keittää kahvia, tukivat vuorovaikutusta ja jatkuvuutta.

Vuorovaikutuksessa puhumisen tapojen ja kielen ymmärrettävyyden merkitys korostui. Yksilöllisyyttä kunnioittava ja kuunteleva puhetapa tuki asukasta säilyttämään autonomiansa ja arvokkuutensa. Kun hallinnollisen ja palvelujärjestelmälähtöisen puheen sijaan käytettiin niin asukkaille kuin läheisillekin ymmärrettävää kieltä, asioista sopiminen helpottui, mikä puolestaan edisti keskinäistä yhteistyötä.

Asukkaan kannustamista ja rohkaisemista itsenäiseen toimintaan pidettiin tärkeänä. Kotiin palveluita tuottavat tahot ja vapaaehtoistoimijat vaikuttivat keskeisesti siihen, kuinka asukkaita ja heidän läheisiään tuettiin ja motivoitiin mahdollisimman normaaliin arkeen ja totutun elämäntavan jatkamiseen muistisairauden kanssa. Turvallisuuden korostaminen ja riskien välttäminen kavensivat asukkaiden mahdollisuuksia tekemisten ja liikkumisen suhteen. Muistisairaus saatettiin myös mieltää sosiaalisesti rajoittavaksi, mitä tuotiin esille esimerkiksi sillä, että joidenkin omaisten mielestä muistisairaana ei ollut soveliasta käydä ostoksilla tai kulttuuritilaisuuksissa.

Yhdessä tekeminen, kuten asiointi tai ulkoi- lu, oli oleellista arjen sujumiselle silloin, kun asukkaiden toimintakyky oli rajoittunut. Ammattihenkilöiden neuvot toimintatavoista selviytyä hankalista tilanteista auttoivat omaisia tukemaan sairastunutta ja jatkamaan yhdessä elämistä. Henkilökunnan joustavat toimenkuvat ja palveluiden toteuttaminen asukaskeskeisesti edistivät yhdessä tekemisen kohdistumista asukkaille merkityksellisiin asioihin.

Asukkaiden hyvinvoinnille merkityksellisten tarjoumien aktualisointia tukivat asumiseen liittyvien tarpeiden ja toiveiden kartoittaminen ja tyytyväisyyskyselyt. Kun asukkaiden hyvinvointia arvioitiin havainnointimenetelmien, kuten Dementia Care Mapping (DCM)tai Elo-D-menetelmien avulla, asiantuntijoiden mukaan saatiin tietoa myös vaikeammin muistisairailta asukkailta. Havaintojen perusteella kokonaisvaltainen kuntouttava työote toteutui erityisesti sellaisissa asumispalveluissa, joissa oli sitouduttu organisaation tasolla ihmiskeskeiseen hoitoon, esimerkiksi gentle care tai green care-lähestymistapoihin.

Asumisen yhteisön monipuolisuus koettiin tavoiteltavana ja elämää rikastuttavana ja nähtävissä olikin pyrkimyksiä monipuolistaa asumisen ympäristöjä. Monisukupolvinen toiminta nähtiin mieluisana. Varsinkin vuorovaikutuksen lasten ja nuorten kanssa katsottiin virkistävän niin mieltä kuin harjoittavan kommunikaatiotaitoja.

Vuorovaikutusta tuettiin teknologian avulla esimerkiksi tekemällä digitaalisia elämäkertoja asukkaista, joiden avulla henkilökunta sai monipuolisen kuvan asukkaan elämänhistoriasta. Elämäkerrat myös ylläpitivät asukkaan identiteettiä vahvistamalla muistikuvia tärkeistä ihmisistä ja merkityksellistä tapahtumista. Jos omaiset eivät pystyneet osallistumaan asukkaiden arkeen, sosiaalinen media, kuten Facebook, tarjosi väylän arjen toiminnan seuraamiseen.

Hyvä vuorovaikutus oli mahdollista muistisairauden eri vaiheissa. Sipoossa toteutetussa asukaskyselyssä vastaajien muistiongelmien koettu vakavuus ei ollut yhteydessä tyytyväisyyteen ihmissuhteisiin tai yksinäisyyden kokemuksiin. 
Muistisairauden eteneminen johtaa usein omasta kodista ympärivuorokautiseen palveluasumiseen muuttamiseen. Vaikka uuteen ympäristöön muuttamisen kielteiset seuraukset hyvinvoinnille tiedostettiin, ei ollut yleistä, että asukas tiesi etukäteen tulevan asuinpaikkansa ja pääsi siihen vaikuttamaan. Päivätoiminnassa ja intervallihoitojaksoilla tulevia asukkaita pyrittiin etukäteen tutustuttumaan tiloihin ja henkilökuntaan, mutta se ei taannut hoitopaikkaa.

\section{Rakennus ja sisätilat}

Rakennukset, niiden sisätilat ja esineistö muovasivat asumisen verkostoa ja vaikuttivat siihen, mitä arjessa oli mahdollista tapahtua. Palveluasumisessa rakennukset ja sisätilat pyrittiin saamaan kodikkaiksi ja sisustus sekä esineet olivat osa kokonaisuutta. Ulkoisten puitteiden tavoitteena oli tukea ajatusta, että asukkailla oli mahdollisuus elää omannäköistä elämää. Kun asukkaat käyttivät omia vaatteitaan ja tavaroitaan, tuettiin samalla jatkuvuutta aikaisempaan elämään. Kodikkaassa ympäristössä toiminta ja ihmisten käyttäytyminen muotoutuivat ennemmin kodinomaisiksi kuin laitosmaisiksi. Tällöin omaisetkin kokivat käyvänsä läheisellään kylässä, ei potilasvierailulla.

Asumisyksiköiden fyysiset tilat vaikuttivat siihen, kuinka vuorovaikutusta syntyi. Laitosmaisuutta pyrittiin välttämään, ja sen vuoksi keskikäytävämallisista ratkaisuista haluttiin eroon. Helposti saavutettavat mielekkään toiminnan tilat, kuten keittiöt, houkuttelivat yhteiseen tekemiseen ja olemiseen.

Tilojen ja siellä tapahtuvan toiminnan näkyvyyttä voitiin parantaa esimerkiksi lasiseinin, jolloin näköhavainto saattoi houkuttaa ohikulkijan mukaan. Oleskelutilojen sijoittaminen kulkureittien varrelle motivoi asukkaita liikkumaan tarjoamalla sekä levähdyspaikkoja että spontaaneja kohtaamisen tiloja. Parhaimmillaan ympäristössä oli monenlaisia tiloja ja tilahierarkia yksityisestä puolijulkiseen ja julkiseen oli luonteva. Kun tilat antoivat mahdollisuuden yksityisyyteen ja vetäytymiseen halutussa seu- rassa, yhdessä olemisesta tuli valittavissa oleva tarjouma eikä pakotettu kokemus, mihin laitosmainen ympäristö helposti johti.

Sisätiloissa liikkumista ja kulkua eri tilojen välillä tuettiin ympäristön esteettömyyden, hahmotettavuuden ja ymmärrettävyyden avulla. Selkeät reitit ja kiintopisteet kulkuväylien varrella auttoivat suuntaamaan kulkua. Materiaaleja, värejä, kontrasteja, valaistusta ja kuvioita voitiin käyttää ohjaamaan, näyttämään suuntia tai estämään liikkumista. Hyvillä tilaratkaisuilla pystyttiin tukemaan muistisairauden eri vaiheissa olevien asukkaiden toimintaa. Sipoon asukaskyselyssä muistiongelmien vakavuus ei ollut yhteydessä siihen, kuinka tyytyväisiä vastaajat olivat asuntonsa esteettömyyteen liikkumisen suhteen.

Teknologiaa, kuten ovihälyttimiä, liesivahteja ja etäyhteyksiä, käytettiin pääasiassa valvontaan ja turvallisuuden varmistamiseen. $\mathrm{Lu}-$ kittu ulko-ovi, jota asukas itse ei saa auki, oli yleinen tapa varmistaa turvallisuutta, mikä rajoitti merkittävästi asukkaiden liikkumista.

\section{Piha ja lähiympäristö}

Pihan ja lähiympäristön liittyminen sisätiloihin ja niiden esteettömyys laajensivat asukkaiden käytettävissä olevaa elintilaa. Näköyhteys sisätiloista pihalle ja laajemmin ympäristöön yhdisti sekä luontoon että paikallisyhteisöön. Luonnon seuraamisen ohella toiminnallisen ympäristön, esimerkiksi koulun tai päiväkodin pihan, katselu saattoi olla mielekästä ja lisätä asukkaiden tunnetta osallisuudesta.

Pihan toiminnallisuudella ja viihtyisyydellä motivoitiin uloslähtemiseen. Tekemisen mahdollisuudet, joita erilaiset ihmiset pystyivät hyödyntämään, edistivät spontaania vuorovaikutusta. Ulkona liikkumisen nähtiin tukevan monipuolisesti toimintakykyä ja sosiaalista vuorovaikutusta. Tarjoumien havaitsemista voitiin tukea toiminnallisten alueiden sijoittamisella näkyville paikoille. Samoin välineiden esillepanolla ja värityksellä motivoitiin toiminnan aloittamiseen. Pihan toiminnallisuus liittyi myös vapaaehtoisten mahdollisuuksiin järjes- 
tää tai olla tukemassa erilaisia aktiviteetteja. Kun pihan oleskelualueet ja ulkoliikuntapaikat olivat myös muiden kuin asukkaiden käytettävissä, asumisen yhteisö avautui lähiympäristöön yhteisen toiminnan tilaksi. Viihtyisyyttä pihoihin luotiin suojaisilla oleskelualueilla, istutuksilla, vesiaiheilla ja taideteoksilla.

Luonnon sisältymisen asumiseen ja hoitotyöhön katsottiin sekä parantavan muistisairaiden asukkaiden elämänlaatua että lisäävän työntekijöiden hyvinvointia. Kasvien ja eläinten hoitaminen oli yleistä joko tavoitteellisena terapiana tai arkeen kuuluvana toimintana. Kaikissa esimerkkikohteissa oli hyviä kokemuksia siitä, kuinka kasvit ja eläimet aktivoivat asukkaiden aisteja, rauhoittivat, tuottivat iloa ja tarkoituksellisen tekemisen mahdollisuuksia sekä tukivat orientaatiota.

Muistisairaiden asukkaiden turvallisuutta varmistettiin usein rajaamalla käytössä oleva piha-alue lukittavalla aidalla, jolloin asukas saattoi mennä ulos itsenäisesti. Rakennuksen sisään jäävä atriumpiha antoi myös mahdol- lisuuden omaehtoiseen ulkoiluun. Kaupunkirakenteessa rakennusten sulkemat korttelipihat nähtiin mahdollisuudeksi toteuttaa turvallisia ulkoilupaikkoja. Kun piha-alue oli riittävän laaja ja sisälsi erilaisia tilallisia elementtejä, kuten kävelypuutarhan ja oleskelualueen, se ei rajaamisesta huolimatta tuntunut suljetulta. Mikäli ulkoilualuetta ei oltu rajattu, asukkaat pääsivät pääsääntöisesti ulos vain joko läheisten, vapaaehtoisten tai henkilökunnan kanssa. Paikantavan teknologian käyttö ulkoilun turvaajana oli vielä vähäistä.

Sipoon asukaskyselyssä lähes kaikki vastaajat (89\%) ilmoittivat pääsevänsä ulos niin usein kuin haluavat. Vastaajien muistiongelmien vakavuus liittyi asuinympäristön koettuun laatuun (Kuvio 3). Vastaajat, joilla oli ilmoituksensa mukaan paljon muistamisvaikeuksia, olivat tyytymättömämpiä asuinalueensa rauhallisuuteen $(p=0,005)$, viheralueisiin $(p=0,015)$, siisteyteen $(p=0,009)$, turvallisuuteen $(p=0,018)$, kauneuteen $(\mathrm{p}=0,009)$ ja liikkumisen helppouteen $(\mathrm{p}=0,016)$.

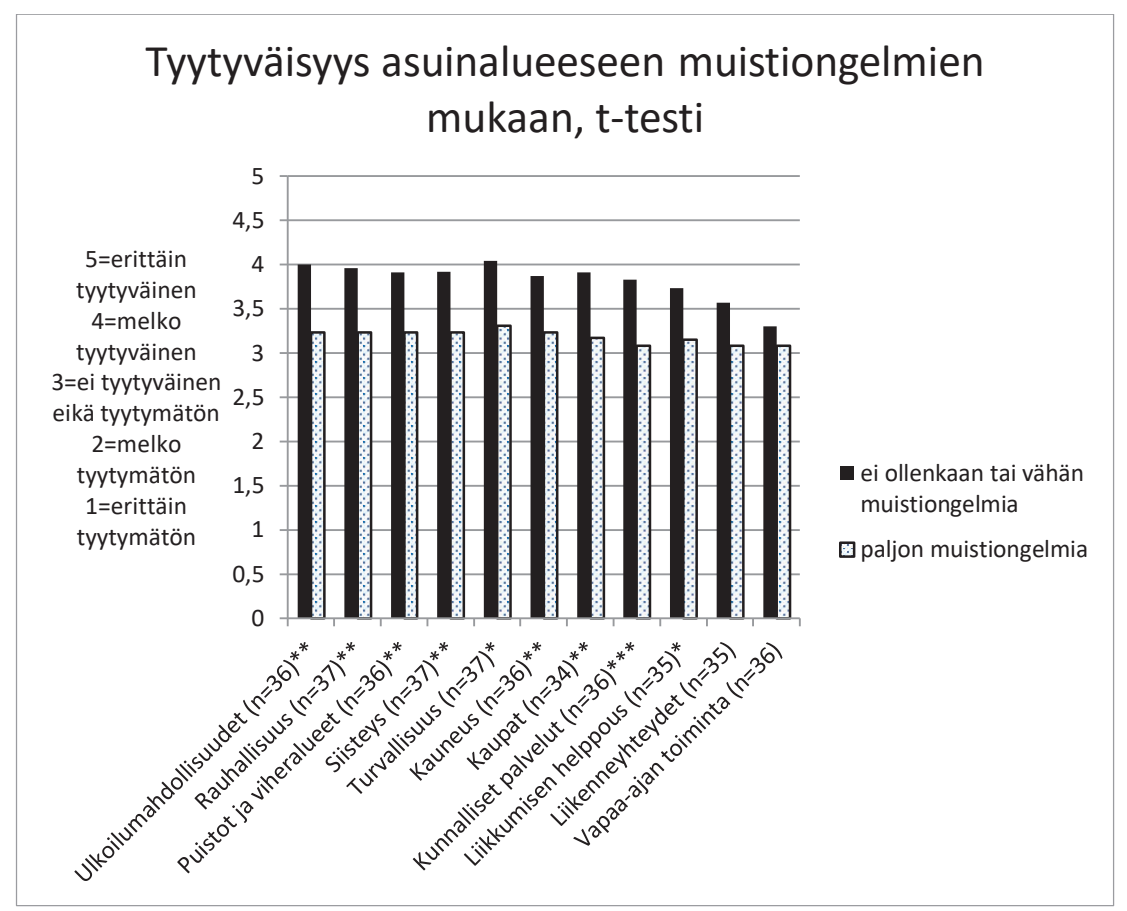

Kuvio 3. Sipoon asumispalveluiden asiakkaiden ( $n=34-37)$ tyytyväisyys asuinalueeseensa muistiongelmien mukaan. Riippumattomien otosten $t$-testi, ${ }^{*}=p<0,05,{ }^{* *}=p<0,01,{ }^{* * * *}=p<0,001$. 
Paikallisyhteisö ja palvelut

Paikallisyhteisön ja palveluiden saavutettavuus olivat yhteydessä siihen, kuinka muistisairas asukas pystyi elämään omassa kodissaan sairautensa kanssa ja käyttämään palveluita. Asukkaiden osallisuutta vahvistavat vuorovaikutuksen mahdollisuudet paikallisyhteisön kanssa aktualisoituivat joko palveluita käytettäessä tai erilaisten tapahtumien yhteydessä.

Liikkumisen ja liikenneyhteyksien esteettömyys ja saavutettavuus koettiin asunnon ulkopuolisten palveluiden käytön kynnystekijöiksi. Palvelujen sijainti kävelyetäisyydellä tuki vuorovaikutusta paikallisyhteisön kanssa ja teki asukkaita näkyväksi omalla alueellaan. Itsenäistä asiointia tuettiin sekä rohkaisemalla asukkaita että valmentamalla palveluiden tuottajia muistisairaiden asiakkaiden kohtaamiseen.

Sipoon asukaskyselyssä tuli esille se, kuinka muistisairauden eteneminen vaikeutti palveluiden käyttöä (Kuvio 3). Vastaajat, jotka kokivat paljon muistamisvaikeuksia, olivat tyytymättömämpiä asuinalueensa liikenneyhteyksiin $(p=0,014)$, kauppoihin $(p=0,004)$, kunnallisiin palveluihin $(p=0,000)$ ja ulkoilumahdollisuuksiin $(p=0,001)$ kuin ne, jotka kokivat jonkin verran tai ei ollenkaan muistamisvaikeuksia.

Asuinalueiden ja palveluiden ikä- ja muistiystävällisyyttä kehitettiin muokkaamalla asenneilmapiiriä ja välittämällä tietoa erilaisten tilaisuuksien, kampanjoiden, median ja monitoimijaisen yhteistyön kautta. Muistisairaiden asukkaiden elämää pyrittiin tekemään näkyväksi ja luonnolliseksi osaksi alueen arkea. Tärkeää oli saada läheiset, naapurusto ja palveluiden tuottajat yhteistyöhön ja ottamaan omalta osaltaan vastuuta tukea tarvitsevan asukkaan hyvinvoinnista.

Osallisuudella paikalliseen tuttuun kulttuuriin pyrittiin vahvistamaan asukkaiden mahdollisuuksia jatkaa totuttua elämäntyyliä. Käytännössä tämä tarkoitti esimerkiksi tapahtumien ja toiminnan järjestämistä yhdessä paikallisten järjestöjen kanssa tai että ruoka valmistettiin paikallisista raaka-aineista tuttujen reseptien mukaan. Tällöin ruoka saattoi tuottaa aistittavan tarjouman, jonka aktualisointi (ruokailu) synnytti emotionaalisen yhteyden elämänkulkuun. Mahdollisuus lähteä metsästys- tai onkiretkelle, hautausmaalle tai keskus$\tan$ kahvilaan ylläpiti totuttua elämäntapaa ja yhteyttä ympäristöön.

Palveluasumisessa koululais- ja päiväkotivierailut tai nuorten työharjoittelut synnyttivät vuorovaikutusta eri sukupolvien välille. Kun laajemmalle asiakaskunnalle kohdistettu palvelu, kuten ravintola tai kirjasto, sijaitsi iäkkäiden asumisen yhteydessä, se monipuolisti vuorovaikutuksen mahdollisuuksia. Jos päiväkoti oli sijoitettu samaan rakennukseen iäkkäiden palveluasumisen kanssa, sukupolvien kohtaamisista tuli osa arkea.

\section{Yhteiskunta}

Yhteiskunnan tasolla kiinnostuksemme kohteena oli asiantuntijahaastatteluissa esiin tullut asumisen hallinnoinnin järjestelmä, missä keskityimme ikääntyneiden palvelujärjestelmään ja asumisen suunnittelujärjestelmään. Iäkkäiden asumista ohjataan sekä valtiollisella että kuntatasolla.

Asumisen ratkaisuihin vaikuttavat niin ikääntymis- ja asumispoliittiset kuin elinkeinopoliittisetkin tavoitteet. Asumiseen vaikutetaan lainsäädännön, hallituksen ja ministeriöiden linjausten ja niihin perustuvien suositusten, kehittämisohjelmien ja -hankkeiden, rahoitusinstrumenttien sekä yhdyskuntasuunnittelun kautta. Asumisen sääntely ja ohjeistus koskevat erityisesti suunnittelu- ja rakentamisvaihetta, mutta valmistumisen jälkeistä tilannetta, kuten valmistuneen rakennuksen tuottaman asumisen laatua, ei kunnolla arvioida. Tämä nähtiin ongelmana.

Kotona asumisen tukeminen kotihoidon ja päivätoiminnan avulla sekä palveluasuminen ja laitoshoito ovat keskeinen osa iäkkäiden asumiseen liittyvää palvelujärjestelmää, jota ohjataan lainsäädännöllä. Laki ikääntyneen väestön toimintakyoyn tukemisesta sekä iäkkäiden so- 
siaali- ja terveyspalveluista (980/2012) painottaa ikääntyneen väestön kotona asumista. Laatusuositus byvän ikääntymisen turvaamiseksi ja palvelujen parantamiseksi 2017-2019 korostaa, että iäkkäiden ihmisten tarpeet otetaan huomioon asuntokannan korjaamisessa ja asuinympäristöjen suunnittelussa ja ylläpidossa (STM ja Kuntaliitto 2017). Suosituksen mukaan asuinympäristöjä tulee kehittää esteettömiksi ja turvallisiksi sekä yhteisöllisyyttä ja osallisuutta tukeviksi asumisen ja palveluiden kokonaisuuksiksi. Ympärivuorokautinen hoito tulisi järjestää kodikkaassa ympäristössä ja asumisen toteutua mieluiten tavanomaisessa asuntokannassa. Suosituksissa korostetaan kunnan eri hallintokuntien ja muiden toimijoiden välistä yhteistyötä asumisen kehittämisessä.

Ikäihmisille suunnatut asumisen yksiköt on rakennettu suurelta osin julkisella tuella ja rakentaminen on ollut pitkälle säänneltyä ja ohjeistettua. Rakentamisen ohjauskeinoista tärkeimpiä ovat Asumisen rahoitus- ja kehittämiskeskuksen (ARA) erityisryhmien investointiavustukset, korkotukilainat ja korjausavustukset. Pääasiallisin ohjaava kriteeri rahoitusinstrumenteissa on pinta-ala, minkä avulla ei voida kattaa kovinkaan hyvin iäkkäiden asumiseen liittyviä laadullisia tavoitteita. Korjausavustusten avulla on parannettu asuntojen esteettömyyttä esimerkiksi rakentamalla hissejä. Vuoden 2017 alusta on voinut saada erityisryhmien asumisen investointiavustuslain mukaista valtion tukea sellaisten toiminnallisten tilojen rakentamiseen, jotka ovat palvelutalon asukkaiden lisäksi suunnattu laajemmin alueen ikääntyneille asukkaille (Laki avustuksista erityisryhmien asunto-olojen parantamiseksi 1281/2004). Rahoitusehtojen väljentäminen avaa näin mahdollisuuksia kehittää vuorovaikutusta tukevaa toimintaa.

Valtio ohjaa asumista myös kehittämisohjelmien avulla. Ympäristöministeriön koordinoimassa Ikääntyneiden asumisen kebittämisohjelmassa 2013-2017 tuotettiin toimintamalleja iäkkäiden asumiseen eri toimijoiden yhteistyöllä. Asumiskulttuurin muotoutumiseen vaikut- tavat myös kansainväliset suuntaukset, kuten Ikäystävällisien kaupunkien (WHO) ja muistiystävällisten yhteisöjen (Alzheimer's Disease International) kehittämisen linjaukset sekä käytännössä toimiviksi osoittautuneet mallit, joista yhtenä esimerkkinä on Hogeweykin muistikylä Hollannissa. Muistikylä-konseptia sovelletaan Helsingin seniorikeskusten kehittämiseen.

Kunnissa iäkkäiden asumiseen vaikutetaan yhdyskuntasuunnittelulla ja palvelutarjonnalla. Kaavoituksessa elinkeino- ja liikennepolitiikka ovat usein ratkaisevassa asemassa ja iäkkäiden asuminen sijoitetaan sinne, minne jää tilaa. Vaikka tavoitteena olisi edistää monimuotoisia asuinalueita ja kotona asumisen mahdollisuuksia, nähtiin, että iäkkäiden asuntojen suunnittelussa ei riittävästi huomioida alueen olemassa olevia palvelurakenteita. Suunnittelutyössä keskitytään paljolti rakennuksiin, mutta liikkumisen ja palveluiden käytön edellytyksiä ei välttämättä oteta riittävästi huomioon. Rakennus voi olla toimiva ja esteetön, mutta piha ja lähiympäristö voivat olla esteellisiä ja mielenkiinnottomia. Muistisairaiden ikäihmisten mahdollisuudet vaikuttaa asumista koskevaan päätöksentekoon nähtiin riittämättöminä, sillä käytössä olevat toimintamallit eivät sitä tukeneet. Haastateltujen asiantuntijoiden mukaan asumisen suunnittelua tulisikin tehdä nykyistä kokonaisvaltaisemmin yhteistyössä eri toimijoiden kanssa.

\section{Pohdinta}

Asumisen tarkasteleminen asumisen yhteisön, rakennuksen ja sisätilojen, pihan ja lähiympäristön, paikallisyhteisön ja palveluiden sekä yhteiskunnan säätely- ja ohjausjärjestelmien muodostamana verkostona avaa näkymiä siihen, miten ne vaikuttavat tarjolla oleviin toiminnan mahdollisuuksiin asuinympäristössä ja muistisairaiden asukkainen mahdollisuuksiin käyttää niitä. Kohtaamiset ihmisten kesken, asumisen tilat ja ympäristö palveluineen synnyttävät asukkaissa kognitiivisia, emotionaalisia ja fyy- 
sisiä vasteita, jotka joko edistävät tai ehkäisevät tarjoumien käyttöä eli aktualisointia. Tulosten perusteella keskeisiksi muistisairaiden asukkaiden hyvän asumisen määrittäjiksi nousivat vuorovaikutukseen liittyvät tekijät - miten monipuolinen vuorovaikutus oli mahdollista ja miten se avasi tai sulki mahdollisuuksia mielekkäälle tekemiselle ja liikkumiselle sekä omannäköiselle elämälle.

\section{Asumisen yhteisö - vuorovaikutus} tarjoumien vartijana

Vuorovaikutus, joka tuki autonomiaa ja turvallisuuden tunnetta sekä edisti yhteisöllisyyttä, oli asukkaiden hyvinvoinnin kannalta merkityksellistä. Mitä avoimempi asumisen yhteisö oli ja mitä enemmän siellä oli toiminnallisia mahdollisuuksia, sitä monipuolisempia vuorovaikutuksen tilanteita se tarjosi.

Toimintakulttuurit ja -mallit, jotka tukivat asukkaiden yksilöllisyyttä ja heille mielekästä tekemistä, edistivät ympäristön tarjoumien käyttöä. Itsenäiseen toimintaan motivoivalla ilmapiirillä voitiin tukea kotona asumista ja edistää elämänlaatua palveluasumisessa. Toiminnallisen itsenäisyyden onkin todettu olevan muistisairaiden ihmisten elämänlaadulle keskeinen tekijä (Marventano ym. 2015). Omaisten, naapuruston ja ammattilaisten muodostamat verkostot, joissa otetaan huomioon muistisairaiden ihmisten voimavarat ja kannustetaan toimintaan, ovat muistiystävällisen yhteisön perusominaisuuksia (Crampton \& Eley 2013). Virkolan mukaan (2014) muilta saatu tuki ja sen liittyminen jo olemassa oleviin sosiaalisiin verkostoihin ja tavanomaisiin palveluihin tuki yksin asuvien muistisairaiden naisten kotona asumista ja totutun elämäntavan jatkumista. Huolehtiva ja hyväksyvä sosiaalinen verkosto voi jopa mahdollistaa kotona asumisen silloinkin, kun muutoin jouduttaisiin muuttamaan palveluasumiseen (Wiersma \& Denton 2016).

Kannustamisen ja rohkaisemisen tärkeys tarjoumien aktualisoinnille toi esille emotionaalisten ja sosiokulttuuristen tekijöiden mer- kityksen asukkaiden toiminnalle. Siihen, kuinka mahdollisuus toimia tulee tarjoumana havaittua ja tulkittua, nähtiin vaikuttavan myös se, kuinka toimijat siitä puhuivat. Muistisairaus herkistää ei-kielelliselle vuorovaikutukselle (Machiels, Metzelthin, Hamers \& Zwakhalen 2017), mikä korostaa vallitsevien asenteiden ja ilmapiirin merkitystä. Jos toiminnan mahdollisuus, kuten palvelu, oli käyttäjälleen vaikeasti ymmärrettävä ja byrokraattinen, se heikensi aktualisoinnin houkuttelevuutta. Topo, Kotilainen ja Eloniemi-Sulkava (2012) nostavat esiin sen, että muistisairaan ihmisen kohdalla se, kuinka avustava henkilö havaitsee tarjouman, vaikuttaa sen aktualisointiin.

Palveluiden tuottajien selkeä sitoutuminen arvopohjaiseen toimintatapaan, kuten gentle care (Jones 1999) tai green care (Sempik, Hine \& Wilcox 2010), liitti eri toimintoja kokonaisuuksiksi ja sitoutti henkilökuntaa yhtenäiseen ymmärrykseen toiminnan merkityksestä asukkaiden hyvinvoinnille. Joustavat toimenkuvat lisäsivät tilannesidonnaisiin tarpeisiin vastaamiseen ja toiveiden toteuttamiseen käytettävissä olevia mahdollisuuksia. Palvelujen arviointi teki näkyväksi toimintatapojen vaikutuksia ja yhdisti ne asukkaiden hyvinvointiin, jolloin palvelut eivät jääneet pelkästään tehdyiksi suoritteiksi.

Asiantuntijat näkivät monisukupolvisen toiminnan asukkaille mieluisana ja varsinkin spontaaneja vuorovaikutustilanteita arvostettiin. Vaikka tutkimustietoa monisukupolvisen toiminnan vaikutuksista muistisairaiden ihmisten hyvinvointiin on vähän ja sekin ristiriitaista (George 2011; Low, Russell \& Kauffman 2015), tämän aineiston perusteella sukupolvien kohtaamista ja yhdessä tekemistä kannattaa edistää, koska sitä kautta elämään tulee kaivattua vaihtelua.

Sipoon kunnassa on useita vuosia edistetty muistiystävällisyyttä tiedonvälityskampanjoin ja tukemalla muistisairaiden asukkaiden osallisuutta omaan yhteisöönsä. Se, että muistiongelmien vakavuus ei vaikuttanut kyselyyn vastanneiden tyytyväisyyteen ihmissuhteisiin tai 
yksinäisyyden kokemuksiin, kertonee toiminnan onnistumisesta.

\section{Rakennus ja sisätilat - kotoisan käytöksen puitteet}

Fyysisten tilojen merkitys sille, millaisia tarjoumia vuorovaikutukselle asumisen yhteisöissä syntyi, oli ratkaisevaa, mikä on havaittu myös aiemmissa tutkimuksissa (Charassa, Eynardb \& Viatoura 2016; Stadnyk, Jurczak, Johnson, Augustine \& Sampson 2013; Yang \& Stark 2010). Selkeästi toiminnallisten tilojen, jotka olivat helposti havaittavissa, nähtiin houkuttelevan asukkaita osallistumaan. Esteettömyydellä ja tukemalla ympäristön hahmottamista edistettiin tarjoumien havaitsemista ja aktualisointia. Kun tilat olivat kodikkaita ja viihtyisiä, ne tukivat asukkaiden omannäköistä elämää ja suuntasivat myös henkilökunnan käyttäytymistä asukaslähtöisemmäksi. Toimintamallien tuotteistaminen voi haastaa asukkaiden omannäköisen elämän puitteiden luomista ja paikallisuuden esille tuomista. Topo ja muut (2012) ovatkin todenneet, että fyysinen hoitoympäristö kuvastaa vallitsevaa hoitoideologiaa ja päätöksenteolle keskeisiä arvoja ja voi rajoittaa muistisairaan asukkaan toimijuutta.

Tilallisen vaihtelun avulla luotiin mahdollisuuksia säädellä vuorovaikutusta tarpeiden mukaan. Tällöin yhdessä tai yksin oleminen ei kumpikaan muodostunut pakotetuksi. Tilahierarkian onkin todettu olevan yhteydessä yhteisöllisyyden syntyyn (Charassa ym. 2016; Stadnyk ym. 2013; Yang \& Stark 2010). Laitosmaisuutta kuvastava keskikäytävämalli rajoitti kohtaamisen tilojen sijoittelua, mikä supisti yhdessä olon ja yhteisen toiminnan mahdollisuuksia.

Muistisairaana asukkaan elämä keskittyi sisätiloihin ja ulospääsyä oli rajoitettu usein lukituilla ovilla. Tämä ilmentää toisaalta sitä, etteivät asuinympäristöt yleisesti ole muistiystävällisiä ja toisaalta sitä, että turvallisuuteen liittyvät vastuukysymykset olivat määrittävämpiä kuin asukkaan autonomia.
Teknologian kautta avautui pääasiassa mahdollisuuksia niihin toimintoihin, jotka liittyivät asukkaiden turvallisuuteen tai hoitoon. Teknologian käyttöön asukkaiden hyvinvoinnin ja viihtyvyyden edistämiseksi kohdistui paljon tulevaisuuden odotuksia, mutta näihin liittyviä sovelluksia oli vielä vähän käytössä.

Sipoon asukaskyselyn mukaan asuntojen esteettömyydessä liikkumisen suhteen ei koettu ongelmia. Fyysinen esteettömyys ei muistisairaille asukkaille välttämättä ole kynnyskysymys, koska liikkumiskyky voi säilyä hyvänä pitkään. On syytä kuitenkin huomata, että palveluasuntoon muutettaessa uuden ympäristön hahmotettavuuden helppous on tärkeää, sillä kotona asuttaessa tilojen tuttuus tukee liikkumista ja toimintaa.

Piha ja lähiympäristö - luonto houkuttaa ulos

Piha-alue ja lähiympäristö määrittivät asukkaiden mahdollisuuksia liikkua sisätiloja laajemmin. Jos liikkumisen rajoittamiseen ei nähty tarvetta tai rajatulle pihalle oli sisältä esteetön pääsy, itsenäinen liikkuminen oli mahdollista. Tämä tuki hyvinvointia, sillä ulkoilun on todettu liittyvän iäkkäiden ihmisten hitaampaan toimintakyvyn heikkenemiseen (Jacobs ym. 2008), parempaan koettuun terveyteen (Rappe, Kivelä \& Rita 2006) ja pystyvyyden tunteeseen (Kono, Kai, Sakato \& Rubenstein 2004) sekä aktivoivan aivojen toimintaa hidastaen kognitiivisten toimintojen heikkenemistä (Erickson ym. 2010; Makizako ym. 2013).

Lähiluonnon merkitys asukkaiden hyvinvoinnille nousi aineistosta selkeästi esiin. Viihtyisät pihat istutuksineen ja eläimineen motivoivat lähtemään ulos, mahdollistivat niin spontaanin kuin tavoitteellisen toiminnallisuuden ja edistivät vuorovaikutustilanteiden syntyä. Viherympäristön terveyttä tukevat vaikutukset erityisesti muistisairaille ihmisille onkin todettu useissa tutkimuksissa (Gonzalez \& Kirkevold 2013; Rappe 2005; Rappe \& Topo 2007). Viheralueita tulisikin tarkastella asumis- 
viihtyvyyden lisäksi hyvinvoinnin näkökulmasta: millaisia toimintakykyä ylläpitäviä ja edistäviä tarjoumia niiden kautta asukkaille avautuu.

Lähiympäristön laatu vaikuttaa siihen, kuinka se koetaan ja mihin tarpeisiin se vastaa. Sipoon kyselyssä ne asukkaat, jotka kokivat paljon muistamisvaikeuksia, olivat tyytymättömämpiä asuinalueensa koettuihin ominaisuuksiin kuin vastaajat, joilla oli jonkin verran tai ei ollenkaan muistamisvaikeuksia. Se, että vaikeampia muistiongelmia kokeneet asukkaat olivat tyytymättömiä asuinalueensa koettuun laatuun, voi kertoa siitä, että mainitut tekijät eivät välittyneet riittävästi aistittavan tiedon kautta tai että he tulkitsivat tiedon kielteisemmin kuin ne asukkaat, jotka kokivat vähemmän muistiongelmia. Rantasen (2015) mukaan ympäristön koettujen piirteiden on todettu ennustavan paremmin iäkkäiden henkilöiden hyvinvointia kuin objektiivisten piirteiden. Jotta asuinympäristöt tukisivat mahdollisimman hyvin myös muistisairaiden asukkaiden hyvinvointia, niiden kokemuksellisen laatu tulisi ottaa suunnittelussa huomioon ja edistää erityisesti myönteisiä tuntemuksia ja tulkintoja tuottavia esteettisiä tekijöitä.

\section{Paikallisyhteisö ja palvelut - saavutettavaa vuorovaikutusta}

Vuorovaikutus paikallisyhteisön kanssa liittyi palveluissa tai tapahtumissa toteutuviin kohtaamisiin. Asuntojen tulisikin olla lähellä palveluja ja tapahtumien paikkoja, mieluiten kävelymatkan tai toimivien julkisten liikenneyhteyksien päässä. Palveluiden käyttö edellyttää, että ne ovat ymmärrettäviä ja esteettömästi saavutettavia.

Sipoon asukaskyselystä muistiongelmien koettu vakavuus oli yhteydessä palveluiden koettuun laatuun. Palveluiden muistiystävällisyyden kehittämiseen tulisikin kiinnittää entistä enemmän huomiota, sillä mahdollisuus käyttää samoja palveluita kuin muut tukee kotona asumista ja ilmentää ympäristön muistiystävällisyyttä (Crampton \& Eley 2013).
Paikallisuuden ja kulttuurisen tuttuuden nähtiin vahvistavan asukkaiden tunnetta jatkuvuudesta ja oman näköisestä elämästä. Yhteisöllisyys ja yhteenkuuluvuuden kokemus ovat muistisairaiden asukkaiden hyvinvoinnille keskeisiä (Brooker ym. 2011) ja tarpeiden mukainen paikalliseen yhteisöön integrointi voi säästää myös terveydenhuollon kustannuksia (Brooker ym. 2011; National Audit Office 2010).

\section{Yhteiskunta - asuminen palveluna}

Yhteiskunnan tasolla korostuivat sääntely, hallinnolliset tavoitteet, ohjauskeinot ja palveluiden järjestäminen. Toimijana yhteiskunta määritti vahvasti asumista yhdyskuntasuunnittelun ja palvelujärjestelmän kautta. Muistisairaan asukkaan omat mahdollisuudet vaikuttaa asumiseensa liittyvien tavoitteiden asettamiseen sekä asumisen ja palveluiden suunnitteluun olivat vähäiset, koska käytössä ei yleisesti ole toimintamalleja, joiden kautta osallistuminen olisi mahdollista.

Palvelujärjestelmä ohjasi tarkastelemaan iäkkäiden asumista palveluina, jota määrittelivät erilaiset kriteerit. Toimintatapa ylläpitää palvelujärjestelmän tehtäväorientoituneisuutta; se voi vaikuttaa kielteisesti tarjoumien sosiokulttuuriseen tulkintaan sekä asukkaiden mutta myös omaisten ja henkilökunnan autonomiaan rajoittavasti. Asumisen laatu muodostuu asukkaan kokemuksena siitä, miten asuinympäristössä toteutuvat hänen hyvinvoinnilleen tärkeät tekijät. Se, kuinka asuinympäristön tarjoumat aktualisoituvat asumisen arjessa kunkin yksilön kohdalla, ei ole palvelutuote, joka voidaan tuoda valmiina toimintamallina, vaan se edellyttää yksilöllisyyden huomioivia toimintatapoja.

\section{Asumisen kehittämisen jännitteiset painopisteet}

Toimijaverkoston näkökulma tuo esille sen, etteivät kaikki asumisen toimijat aina ohjaa toimintaa samaan suuntaan. Eri toimijoilla voi 
olla erilaisia tavoitteita ja näkökulmia, joiden välillä on tasapainoiltava. Esimerkiksi palveluasumisen yksiköt näyttäytyvät erilaisilta silloin, kun niitä katsotaan asumispalveluina, joiden tulee vastata asukkaidensa yksilöllisiin toiveisiin ja tarpeisiin tai silloin kun niitä katsotaan asumisyhteisöinä, joissa kaikkien osallisuus ja yhdenvertaisuus ovat keskeisiä. Se, että sairauden edetessä jouduttiin muuttamaan sinne missä oli vapaa hoitopaikka, toi esille, kuinka palvelujärjestelmän toimijat määrittivät varsin suoraviivaisesti asumisen yhteisön ja ne olosuhteet, joissa kodinomaisuuden tavoitteen oli toteuduttava.

Toimijaverkoston ja tarjoumateorian näkökulmasta rakennetun ympäristön elementit ovat toiminnan esteitä ja mahdollisuuksia kantavia toimijoita, joihin "sementoituneet" tavoitteet ohjaavat asumista vielä silloinkin, kun vallalla on jo uudet ihanteet ja pyrkimykset. Esimerkiksi hissittömät kerrostalot ja laitosmaiset tilaratkaisut asettavat edelleen omat reunaehtonsa iäkkäiden kotona asumisen tukemiselle ja palveluasumisen kodinomaisuuden kehittämiselle.

Toisinaan rakennus tiloineen voi ylläpitää erilaisia tavoitteita kuin se yhteisö, joka kyseisessä rakennuksessa asuu. Entiseen laitosyksikköön perustetussa palvelutalossa tilat voivat suunnata toimintaa laitosmaiseksi, vaikka pyrkimyksenä olisi kodinomaisuuden ja yhteisöllisyyden korostaminen. Tilojen arkkitehtuuri asettaa reunaehdot sille, mitä niissä voi tehdä. Nord (2015) huomasi tarkastellessaan lyhytaikaisen hoidon yksiköitä toimijaverkkoteorian näkökulmasta, että sillä, majoittuiko hoitoa tarvitseva henkilö yhden vai kahden hengen huoneeseen, oli merkitystä hoidon ja sosiaalisten suhteiden muotoutumiselle. Potilaskeskeisen hoitoideologian toteuttaminen oli Nordin mukaan vaikeaa kahden hengen huoneissa.

Muistisairaiden ihmisten asumisessa halutaan yhtäältä korostaa asukkaiden vapautta, itsenäisyyttä ja itsemääräämisoikeutta ja toisaalta turvallisuutta, mikä johtaa helposti toiminnan ja liikkumisen rajoittamiseen. Vapaan mut- ta turvallisen liikkumisen osalta seurantateknologia voi tarjota ratkaisuja ja edistää vuorovaikutusta ja yhteisöllisyyttä sekä parantaa kotona asumisen mahdollisuuksia (Riikonen \& Palomäki 2014). Seurantateknologia voi myös vähentää työtekijöiden vuorovaikutusta asukkaan kanssa rajoittaen inhimillisiä kontakteja ja eristäen asukkaita omaan kotiin tai huoneeseen.

Yhdyskuntasuunnittelussa normaaliuden periaatteen mukaan erityisryhmien asumisen tulisi rinnastua tavanomaiseen asumiseen ja muistisairaiden ihmisten asuminen olisi sijoitettava tavanomaiseen asuntokantaan. Muistikylä-konsepti, jossa asumista keskitetään rajatusti muuhun ympäristöön avautuviksi paikallisyhteisöikseen, on vastakkainen yhdyskuntasuunnittelun normaaliuden painotukselle. Rajoittunut elinpiiri voi heikentää myös asukkaiden hyvinvointia, sillä se vähentää liikkumista ja ulkoilua sekä nopeuttaa kognitiivisten toimintojen heikkenemistä (James, Boyle, Buchman, Barnes \& Bennett 2011; Kono, Kai, Sakato \& Rubenstein 2007). Olisikin mietittävä, miten ajatusta muistikylistä ja muistisairaiden ihmisten vapaasta liikkumisesta voidaan edistää ilman, että se johtaa muusta asuntokannasta eriytyviin, suljettuihin alueisiin.

Myös rakentamista ohjaavat rahoitusmallit voivat ilmentää vastakkaisia pyrkimyksiä. Keskeisenä pidetään sitä, että iäkkäiden erityisasuminen sijoitetaan osaksi tavanomaista asumista niin, ettei se erotu muusta asumisesta. Toisaalta voidaan nähdä, että erityisryhmien sijoittamisella samaan kohteeseen tai lähelle toisiaan saavutetaan synergiaetua. Rahoitusehdot eivät kuitenkaan salli erilaisten erityisryhmien, kuten nuorten kehitysvammaisten ja muistisairaiden ikäihmisten, sijoittamista samaan kohteeseen. Eri ikäihmisten ryhmät, kuten muistisairaat ja fyysisen sairauden vuoksi apua tarvitsevat, voivat kuitenkin asua samassa yksikössä, vaikka heidän yhteisasumisessaan voi olla haasteita (Roth, Eckert, Morgan \& Leslie 2016). Tällöin voidaan nähdä, että muistisairaat hyötyvät siitä, että he asuvat tasavertaisesti muiden 
tukea tarvitsevien ikäihmisten kanssa tai ajatella niin, että muistisairaat tarvitsisivat juuri heille räätälöityjä palveluita.

Rahoitusmallit vaikuttavat myös asuntojen ja yhteistilojen kokoon ja niiden väliseen suhteeseen: aina ei voida rakentaa sekä yhteistiloja että asukashuoneita tilaviksi, vaan joudutaan valitsemaan niiden välillä, mikä vaikuttaa asukkaiden yksityisyyden ja yhteisöllisyyden mahdollisuuksiin.

Tarjouman käsite perustuu transaktionaaliseen ympäristösuhteeseen, jolloin yksilöä ja ympäristöä voidaan tarkastella yhdenvertaisista lähtökohdista (Kyttä \& Kahila 2006). Asumispalveluiden tarkastelu tarjoumateorian kautta avaa mahdollisuuksia lievittää näkökulmien kahtiajakautuneisuutta asukkaisiin palveluiden vastaanottajina ja palvelujärjestelmään palveluiden tuottajina ja hälventää niiden välisiä jännitteitä.

Kun ristiriitoihin, jotka juontuvat asukkaiden kodin ja yhteiskunnan sääntelemän työpaikan sijaitsemisesta samassa tilassa, sovelletaan näkökulmaa, jossa ympäristöä tarkastellaan tarjoumista avautuvien yksilöllisten kokemuksien kautta, voidaan eri toimijoiden tarpeita helpommin ymmärtää ja sovittaa yhteen. Tällöin esimerkiksi turvallisuutta voidaan tarkastella tilanteittaisina tarjoumina ilman, että tietty näkökulma on määräävässä asemassa. Tarjoumateorian avulla voidaan myös ymmärtää paremmin tilanteita, joissa palvelu ei vastaa käyttäjän yksilöllisiä tarpeita tai sitä ei haluta käyttää. Palvelun kautta syntyvä toiminnan mahdollisuus voi olla asukkaalle merkityksetön tai se voidaan kokea negatiivisena, jolloin asukas osoittaa autonomiaansa kieltäytymällä sen aktualisoinnista. Muistisairaille asukkaille tunnetilojen ja toiminnan mielekkyyden vaikutus tarjoumien aktualisointiin on ratkaisevaa.

\section{Tulosten luotettavuuden arviointi}

Tässä kuten useissa muistisairaita ihmisiä koskevassa tutkimuksessa informantteina olivat pääasiallisesti muut henkilöt kuin muistisairaat itse, mikä heikentää tulkintojen pätevyyttä kuvata muistisairaille asukkaille oleellisia asumisen tekijöitä. Käytetty aineisto korostaa myös asiantuntijoiden ja palvelujärjestelmän näkemystä, sillä kaikki haastateltavat olivat yhtä muistisairasta kotona asuvaa henkilöä lukuun ottamatta joko ikäihmisille palveluita tuottavien tai hankkivien tahojen tai palveluiden suunnitteluun ja kehittämiseen osallistuvien toimijoiden edustajia. Koska tutkimuksen tavoitteena oli nostaa esiin tekijöitä, jotka tulisi huomioida asumisen kehittämisessä, asiantuntijanäkemyksiin perustuva aineisto antoi mahdollisuuden löytää niitä tekijöitä, joihin voidaan vaikuttaa kyseisten toimijoiden kautta. Kyselyaineisto valaisi muistisairaiden asukkaiden kokemuksia ympäristön laadusta yhdessä kunnassa, mikä paransi aineiston kattavuutta.

Aineisto painottui Asuva-hankkeen tavoitteen mukaisesti tekijöihin, jotka liittyivät asumisen yhteisöllisyyteen ja sen yhteyksiin koettuun hyvinvointiin. Koska yhteisöllisyyden edellytykset ovat osoittautuneet niin Asuvahankkeessa (Jolanki ym. 2017) kuin aiemmissakin tutkimuksissa (Brooker ym. 2011; Ericsson, Hellström \& Kjellström 2011) muistisairaiden ihmisten hyvinvoinnille merkittäväksi tekijäksi, aineisto kuvannee yleisemminkin hyvää asumista. Esimerkkikohteet oli valikoitu edustamaan sijainniltaan ja toimijoiltaan erilaisia paikkoja, jotka edustivat hyviä asumisen malleja. Tämän vuoksi tekijät, jotka olivat yhteydessä asuinympäristöön liittyviin kielteisiin kokemuksiin, olivat aineistossa aliedustettuja. Tutkimuksen suuntautumista liiallisesti positiivisiin tarjoumiin on kritisoitu aiemminkin (Kyttä 2003). Toisaalta asiantuntijoiden haastatteluissa asumisen suunnitteluun ja järjestämiseen liittyviä haasteita nousi esille.

Aineisto koostui pääosin laadullisesta haastattelu- ja havainnointiaineistosta, mutta sitä täydennettiin asukkaiden lomakekyselyllä, jota analysoitiin tilastollisin menetelmin. Monipuolinen ja eri maista kerätty aineisto auttoi hahmottamaan muistisairaiden ihmisten hyvään 
asumiseen liittyvien tekijöiden kokonaisuutta, mutta runsaudessaan ja monitahoisuudessaan se oli vaikeasti koossa pysyvää.

Aineiston analyysi oli monivaiheinen. Aluksi aineistoa analysoitiin yhteisöllisyyden näkökulmasta Asuva-hankkeessa,jonka jälkeen sitä jäsennettiin toimijoiden ja tarjoumien suhteen kirjoittajien vuoropuhelussa. Tulosten luotettavuutta on varmistettu hakemalla kirjoittajien kesken yhteisymmärrystä tulkinnoissa ja palaamalla toistuvasti aineistoon.

Tutkimuksessa noudatettiin hyvää tieteellistä käytäntöä ja kohdattiin sekä kohteiden asukkaat että haastateltavat arvostavasti. Kyselytutkimukseen, jossa vastaajina olivat asumispalveluiden iäkkäät ja muistisairaat asiakkaat, haettiin lupa Sipoon kunnan vanhuspalveluista ja se toteutettiin vastaajien suostumukseen ja vapaaehtoisuuteen perustuen huomioiden muistisairauksien aiheuttamat erityispiirteet. Esimerkkikohteissa kuvaamiseen pyydettiin lupa eivätkä asukkaat ole tunnistettavissa niissä otetuissa kuvissa. Myöskään haastatellut, esimerkkikohteiden asukkaat ja henkilökunta eivät ole tulosten raportoinnista tunnistettavissa.

Tutkimus toi esille, että tehtäväkeskeisyyden sijaan vanhustyössä on alettu ottaa käyttöön joustavampia toimintatapoja, joilla pyritään vastaamaan paremmin asukkaiden yksilöllisiin tarpeisiin ja antamaan työtekijöille mahdollisuus käyttää omaa osaamistaan ja kiinnostustaan paremmin työtehtävissä. Sitä, mikä vaikutus joustavammilla toimintatavoilla on asukkaiden toiminnan ja vuorovaikutuksen mahdollisuuksiin ja henkilökunnan työhyvinvointiin, tulisi tutkia. Arviointitietoa käytetään asumisen ohjauksessa ja suunnittelussa vähän. Kysymystä siitä, tuottaisiko arviointitiedon nykyistä laaja-alaisempi kerääminen ja hyödyntäminen parempaa asumisen koettua laatua ja sitä kautta asukkaiden hyvinvointia, ansaitsisi tutkia.

\section{Johtopäätökset}

Toimijaverkkoteorian ja tarjoumateorian avulla muistisairaiden ihmisten asumista voidaan tarkastella kokonaisvaltaisesti tunnistaen eri toimijoiden yhteyksiä asukkaalle merkityksellisiin toimintamahdollisuuksiin ja niiden aktualisointiin.

Toimintamahdollisuuksien tarkastelussa on tärkeää ottaa huomioon sekä toimintaan osallistuvat inhimilliset toimijat että rakenteelliset tekijät. Mikäli ne eivät tue toisiaan, toiminta voi vaikeutua tai täysin estyä. Hyvän asumisen kannalta tärkeänä pidetyt asiat eivät ole aina yhteensopivia tai samansuuntaisia vaan asumiseen liittyy tavoitteita, joiden välillä on tasapainoiltava. Etenkin asumispalveluissa tarjoumiin ja niiden aktualisointiin vaikuttavat sosiokulttuuriset tekijät sekä niihin liittyvät ristiriitaiset intressit olisi tiedostettava, jotta kokemus asumisesta muodostuisi hyvinvointia tukevaksi.

Asumisen kehittämisessä tulisi kiinnittää huomiota vuorovaikutukseen, liikkumisen ja mielekkään tekemisen tukemiseen ja välttää niiden fyysisistä tai sosiaalista rajoittamista. Rakenteellisilla tekijöillä, sääntelyllä ja hallinnon keinoin voidaan luoda yhteisiä edellytyksiä toiminnalle mutta siihen, miten muistisairas asukas niitä asumisessaan hyödyntää, vaikuttaa se, kuinka hän tarjoumat havaitsee ja miten hän ne tunteiden tasolla vuorovaikutustilanteissa tulkitsee.

\section{Yhteydenotto}

Erja Rappe, MMT, dosentti

Ikäinstituutti

erja.rappe@ikainstituutti.fi 


\section{Kirjallisuus}

Araujo, M. T., Velloso, I. S. C., Ceci, C. \& Purkis, M. E. (2019). The significance of overlooked objects: Materiality and care at home for people with dementia. Nursing Inquiry 27 (1), 1-8. doi: 10.1111/nin.12306

Banerjee, S., Smith, S. C., Lamping, D. L., Harwood, R. H., Foley, B., Smith, P., Murray, J., Prince, M., Levin, E., Mann, A. \& Knapp, M. (2006). Quality of life in dementia: more than just cognition. Ananalysis of associations with quality of life in dementia. Journal of Neurology, Neurosurgery $\varepsilon^{\circ}$ Psychiatry 77(2), 146-148.

Brooker, D., Argyle, E., Scully, A. J. \& Clancy, D. (2011). The enriched opportunities programme for people with dementia: a cluster-randomised controlled trial in ten extra care housing schemes. Aging and Mental Health 15, 1008-1017.

Callon, M. (1986). The sociology of an actor-network: The case of the electric vehicle. Teoksessa Callon, M., Law, J. \& Rip, A. (toim.), Mapping the Dynamics of Science and Technology: Sociology of Science in the Real World (s. 19-34). London: Macmillan.

Cañal-Bruland, R. \& van der Kamp, J. (2015). Embodied perception: a proposal to reconcile affordance and spatial perception. i-Perception 6 (2), 63-66. doi:10.1068/i0709jc.

Charrasa, K., Eynardb, C., Viatoura, G. (2016). Use of space and human rights: planning dementia friendly settings. Journal of Gerontological Social Work 59 (3), 181-204.

Chemero, A. (2003). An outline of a theory of affordances. Ecological Psychology 15 (2), 181-195. doi:10.1207/S15326969ECO1502_5.

Chen, L.-H. \& Liu, Y.-C. (2017). Affordance and intuitive interface design for elder users with dementia. Procedia CIRP 60, 470-475. doi: 10.1016/j.procir.2017.02.015.

Crampton, J. \& Eley, R. (2013). Dementia-friendly communities: What the project "Creating a dementia-friendly York". Working with Older People 17 (2), 49-57.

Driessen, A. (2019). Dementia Matters: User-Building Interactions Shaping Institutional Life in the Netherlands. Medical Antbropology 39 (3), 225238. doi: 10.1080/01459740.2019.1589464.

Dewitte, L., Vandenbulcke, M. \& Dezutter, J. (2019). Meaning in life matters for older adults with Alzheimer's disease in residential care: associa- tions with life satisfaction and depressive symptoms. International Psychogeriatrics 31, 607-615.

Erickson, K. I., Raji, C. A., Lopez, O. L., Becker, J. T., Rosano, C., Newman, A. B., Gash, H. M., Thompson, P.M., Ho, A. J. \& Kuller, L. H. (2010). Physical activity predicts gray matter volume in late adulthood: The Cardiovascular Health Study. Neurology 75 (16), 1415-1422. doi:10.1212/WNL.0b013e3181f88359.

Ericsson, I., Hellström, I. \& Kjellström, S. (2011). Sliding interactions: An ethnography about how persons with dementia interact in housing with care for the elderly. Dementia 10, 523-538.

George, D. R. (2011). Intergenerational volunteering and quality of life: mixed methods evaluation of a randomized control trial involving persons with mild to moderate dementia. Quality of Life Research 20, 987-995.

Gibson, J. J. (1979). The Ecological Approach to Visual Perception. London: Houghton Mifflin.

Gonzalez, M.T. \& Kirkevold, M. (2013). Benefits of sensory garden and horticultural activities in dementia care: a modified scoping review. Journal of Clinical Nursing 23 (19-20), 2698-2715. doi:10.1111/jocn.12388.

Hadjri, K., Rooney, C. \& Faith, V. (2015). Housing choices and care home design for people with dementia. Health Environments Research E Design Journal 8 (3), 80-95.

Heft, H. (2010). Affordances and the perception of landscape: An inquiry into environmental perception and aesthetics. Ward Thompson, C., Aspinall, P. \& Bell, S. (toim.). Innovative Approaches to Researching Landscape and Health. Open Space: People Space 2 (s. 9-32). New York: Routledge.

Jacobs, J. M., Cohen, A., Hammerman-Rozenberg, R., Azoulay, D., Maaravi, Y. \& Stessman, J. (2008). Going outdoors daily predicts long-term functional and health benefits among ambulatory older people. Journal of Aging and Health 20 (3), 259-272. doi:10.1177/0898264308315427.

James, B. D., Boyle, P. A., Buchman, A. S., Barnes, L. L. \& Bennett, D. A. (2011). Life space and risk of Alzheimer disease, mild cognitive impairment, and cognitive decline in old age. American Journal of Geriatric Psychiatry, 19 (11), 961-969. doi:10.1097/JGP.0b013e318211c219

Jolanki, O., Leinonen, E., Rajaniemi, J., Rappe, E., Räsänen, T., Teittinen, O. \& Topo, P. (2017). 
Asumisen yhteisöllisyys ja hyvä vanhuus. Valtioneuvoston selvitys- ja tutkimustoiminnan julkaisusarja 47/2017. Valtioneuvoston kanslia. Saatavilla http://tietokayttoon.fi/documents/10616/3866814/47_ASUVA-loppuraportti+2017_NETTI.indd.pdf/81ebc84d-3636 $-4314-\mathrm{a} 2 \mathrm{~d} 5-\mathrm{a} 223 \mathrm{~b} 38 \mathrm{~d} 30 \mathrm{~d} 4$ ? version=1.0.

Jones, M. (1999). Gentlecare: Changing the Experience of Alzheimer's Disease in a Positive Way. Point Roberts, WA: Hartley \& Marks.

Kitwood, T. \& Bredin, K. (1992). Towards a theory of dementia care: personhood and well-being. Ageing and Society 12, 269-287.

Kono, A., Kai, I., Sakato, C. \& Rubenstein, L. Z. (2004). Frequency of going outdoors: A predictor of functional and psychosocial change among ambulatory frail elders living at home. Journals of Gerontology, Series A, Biological Sciences and Medical Sciences, 59 (3), 275-280.

doi:10.1093/gerona/59.3.M275.

Kono, A., Kai, I., Sakato, C. \& Rubenstein, L. Z. (2007). Frequency of going outdoors predicts long-range functional change among ambulatory frail elders living at home. Archives of Gerontology and Geriatrics 45 (3), 233-242. doi:10.1016/j.archger.2006.10.013.

Kullman, K. \& Pyyhtinen, O. (2015). Toimijaverkosto. Teoksessa Eriksson, K. (toim.), Verkostot yhteiskuntatutkimuksessa (s. 109-126). Helsinki: Gaudeamus.

Kyttä, M. (2002). Affordances of children's environments in the context of cities, small towns, suburbs and rural villages in Finland and Belarus. Journal of Environmental Psychology 22 (1-2), 109-123. doi:10.1006/jevp.2001.0249.

Kyttä, M. (2003). Children in outdoor contexts. Affordances and independent mobility in the assessment of environmental child friendliness. Yhdyskuntasuunnittelun tutkimus- ja koulutuskeskuksen julkaisuja A 28. Helsinki: Teknillinen korkeakoulu.

Kyttä, M. (2004). The extent of children's independent mobility and the number of actualized affordances as criteria for child-friendly environments. Journal of Environmental Psychology 24 (2), 179-198. doi:10.1016/S0272-4944(03)00073-2.

Kyttä,M. \& Kahila, M. (2006). PehmoGIS. Elinympäristön koetun laadun kartoittaminen. Yhdyskuntasuunnittelun tutkimus- ja koulutuskeskuksen julkaisuja B90. Helsinki: Teknillinen korkeakoulu.

Laki avustuksista erityisryhmien asunto-olojen parantamiseksi 30.12.2004/1281.
Laki ikääntyneen väestön toimintakyvyn tukemisesta sekä iäkkäiden sosiaali- ja terveyspalveluista 28.12.2012/980.

Latour, B. (2005). Reassembling the Social. An Introduction to Actor-Network-Theory. Oxford \& New York: Oxford University Press.

Low, L-F, Russell, F. \& Kauffman, A. (2015). Grandfriends, an intergenerational program for nursing-home residents and preschoolers: a randomized trial. Journal of Intergenerational Relationships 13(3), 227-240.

Machiels, M., Metzelthin, S. F., Hamers, J. P. H. \& Zwakhalen, S. M. G. (2017). Interventions to improve communication between people with dementia and nursing staff during daily nursing care - a systematic review. International Journal of Nursing Studies 66, 37-46.

Makizako, H., Doi, T., Shimada, H., Park, H., Uemura, K., Yoshida, D., Tsutsumimoto, K., Anan, Y. \& Suzuki,T. (2013). Relationship between going outdoors daily and activation of the prefrontal cortex during verbal fluency tasks (VFTs) among older adults: A near-infrared spectroscopy study. Archives of Gerontology and Geriatrics 56 (1), 118123. doi:10.1016/j.archger.2012.08.017.

Marventano, S., Prieto-Flores, M.-E., Sanz-Barbero, B., Martín-García, S., Fernandez-Mayoralas, G., Rojo-Perez, F., Martinez-Martin, P. \& João Forjaz, M. (2015). Quality of life in older people with dementia: A multilevel study of individual attributes and residential care center characteristics. Geriatrics $\mathcal{E}$ Gerontology International 15, 104-110.

McMillan, D. W. \& Chavis, D. M. 1986. Sense of Community: A Definition and Theory. Journal of Community Psychology 14 (1), 6-23.

Milte, R., Shulver, W., Killington, M., Bradley, C., Ratcliffe, J. \& Crotty, M. (2016). Quality in residential care from the perspective of people living with dementia: The importance of personhood. Archives of Gerontology and Geriatrics 63, 9-17.

National Audit Office 2010. Improving dementia services in England - An interim report. Report by the comptroller and auditor general. London: The Stationery Office. Saatavilla https://www.nao. org.uk/wp-content/uploads/2010/01/091082. pdf.

Nord, C. (2015). Architectural Space in Respite and Intermediate Care: An Actor-Network Theory Analysis. Journal of Housing for the Elderly, 29 (1-2), 9-23. doi:10.1080/02763893.2015.989119 
Rantanen, T. (2015). Iäkkäiden ihmisten elinpiiri. Teoksessa Häkli, J., Vilkko, R. \& Vähäkylä, L. (toim.), Kaikki kotona? Asumisen uudet tuulet (s. 93-102). Helsinki: Gaudeamus.

Rappe, E. (2005). The influence of a green environment and horticultural activities on the subjective well-being of the elderly living in long-term care. Publications no 24. Department of Applied Biology, University of Helsinki. Helsinki: Yliopistopaino.

Rappe, E., Kivelä, S.-L. \& Rita, H. (2006). The effect of visiting outdoors green environment on self-rated health among the elderly in long-term care. Hort Technology 16 (1), 55-59.

Rappe, E., Kotilainen. H., Rajaniemi, J. \& Topo, P. (2018). Muisti- ja ikäystävällinen asuminen ja asuinympäristö. Ympäristöopas 28. Helsinki: Ympäristöministeriö.

Rappe, E. \& Topo, P. (2007). Contact to outdoors greenery can support competence among people with dementia. Journal of Housing for the Elderly 21 (3-4): 229-248.

Riikonen, M. \& Palomäki, S.-L. (2014). Seurantateknologia muistisairaan ihmisen näkökulmasta - autonomiaa vai tunkeilevuutta? Gerontologia 28 (3), 143-155.

Roth, E. G., Eckert, J. K., Morgan, L. A. \& Leslie, A. (2016). Stigma and discontinuity in multilevel senior housing's continuum of care. The Gerontologist 56 (5), 868-876.

de Rooij, A. H., Luijkx, K. G., Schaafsma, J., Declercq, A. G., Emmerink, P. M. \& Schols, J. M. (2012). Quality of life of residents with dementia in traditional versus small-scale long-term care settings: A quasi-experimental study. International Journal of Nursing Studies 49, 931-940.

Sempik, J., Hine, R. \& Wilcox, D. (toim.) (2010). Green care: A Conceptual Framework. A report of the working group on the health benefits of green care. COST 866, Green Care in Agriculture. Loughborough, UK: Loughborough University.

Sosiaali- ja terveysministeriö ja Kuntaliitto (2017). Laatusuositus byvän ikääntymisen turvaamiseksi ja palvelujen parantamiseksi 2017-2019. Sosiaali- ja terveysministeriön julkaisuja 6/2017. Helsinki: Sosiaali- ja terveysministeriö ja Kuntaliitto. Stadnyk, R. L., Jurczak, S. C., Johnson, V., Augustine, H. \& Sampson, R. D. (2013). Effects of the physical and social environment on resident-family member activities in assisted living facilities for persons with dementia. Seniors Housing E Care Journal 21 (1) 36-52.

Testad, I., Corbett, A., Aarsland, D., Osland Lexow, K., Fossey, J., Woods, B. \& Ballard, C. (2014). The value of personalized psychosocial interventions to address behavioral and psychological symptoms in people with dementia living in care home settings: a systematic review. International Psychogeriatrics 26 (7), 1083-1098. doi:10.1017/S1041610214000131.

Topo, P., Kotilainen, H. \& Eloniemi-Sulkava, U. (2012). Affordances of the care environment for people with dementia - An assessment study. Herd 5 (4), 118-138.

Tuomi, J. \& Sarajärvi, A. (2013). Laadullinen tutkimus ja sisällönanalyysi. Helsinki: Tammi.

Virkola, E. (2014). Toimijuutta, refleksiivisyyttä ja neuvotteluja - muistisairaus yksinasuvan naisen arjessa. Jyväskylä studies in education, psychology and social research, 491/2014. Jyväskylä: Jyväskylän yliopisto.

Wiersma, E. C. \& Denton, A. (2016). From social network to safety net: Dementia-friendly communities in rural northern Ontario. Dementia 15 (1), 51-68.

Yang, H.-Y. \& Stark, S. L. (2010). The role of environmental features in social engagement among residents living in assisted living facilities. Journal of Housing For the Elderly 24, 28-43.

Ympäristöministeriö (2013). Ikääntyneiden asumisen kehittämisohjelma vuosille 2013-2017.Valtioneuvoston periaatepäätös 18.4.2013. 